УДК 620.179

DOI: https://doi.org/10.36910/6775-2313-5352-2019-15-12

О. Середюк, д.т.н., Н. Малісевич, аспірантка

Івано-Франківський національний технічний університет нафти і газу

\title{
ДОСЛІДЖЕННЯ ВПЛИВУ КОНСТРУКТИВНИХ ФАКТОРІВ НА ТЕХНІЧНУ РЕАЛІЗАЦЮЮ МЕТОДУ ЕКСПРЕС-КОНТРОЛЮ ТЕПЛОТИ ЗГОРАННЯ ПРИРОДНОГО ГАЗУ
}

Анотація. Проведено аналіз відомих нормативних методів $і$ технічних рімень для розрахункового і експериментального методу визначення теплоти згорання природного газу. Обгрунтовано необхідність визначення теплоти згорання вологого природного газу у споживачів за місием роботи газоспоживного обладнання. Викладено технічне рімення для реалізації запатентованого авторами способу визначення теплоти згорання природного газу прямим методом за температурою згорання газу. Кількісно оцінена зміна відносної похибки визначення теплоти згорання природного газу від вологи газу і вологи повітря для умов реалізації запропонованого способу визначення теплоти згорання для конкретних трьох проб газу з теплотою згорання $7759 \kappa \kappa a л / \mathrm{m}^{3}, 8145 \kappa \kappa a л / \mathrm{m}^{3}$ та $8538 \mathrm{\kappa \kappa aл} / \mathrm{m}^{3}$. Встановлені закономірності зміни відносної похибки визначення теплоти згорання від двох складових вологості. Здійснене моделювання відносної похибки визначення теплоти згорання природного газу одночасно від його вологості i вологості навколишнього повітря. Досліджено вплив конструктивних факторів, які впливають на технічну реалізацію методу експрес-контролю теплоти згорання природного газу. Встановлено наявність суттєвого градієнта температури вздовж поверхні тонкої пластини та набагато менше ї̈ значення для грубшої пластини. Досліджені динамічні характеристики нагрівання пластини $і$ термопари при вимірюванні температури полум'я.

Ключові слова: природний газ, теплота згорання, вологість газу, вологість повітря, термоперетворювачі, температура полум'я.

Актуальність задачі. 3 врахуванням світової тенденції підвищення цін на енергоносії, в тому числі на природний газ, актуальним $є$ питання забезпечення необхідної точності вимірювань з врахуванням нових сучасних концепцій до реалізації його обліку. Міжнародний досвід [1,2] і чинний в Україні національний стандарт [3] рекомендує здійснювати облік природного газу інформаційно-вимірювальними системами, які забезпечують вимірювання не тільки використаного об'єму газу, але і враховувати при цьому його теплоту згорання. Це дозволяє здійснювати облік газу в одиницях енергії і безпосереднім чином впливати на його вартість.

З урахуванням такого підходу як доповнення до вузлів обліку природного газу переважно застосовують лабораторні хроматографи, які забезпечують розрахунковий метод визначення теплоти згорання природного газу. Проте такий метод практично неможливо реалізувати безпосередньо у споживачів, в тому числі і у населення, через значну вартість такого обладнання і практичну відсутність мобільних дешевих хроматографів. Тому актуальною $\epsilon$ розробка нових експрес-методів визначення теплоти згорання природного газу, які могли би бути реалізовані і у споживачів газу.

Тому вивчення питання удосконалення пристроїв для вимірювання і контролю теплоти згорання природного газу $є$ актуальною задачею наукових досліджень, яка відкриває нові шляхи раціонального і ефективного використання енергетичних ресурсів, до яких відноситься природний газ.

Аналіз останніх досліджень і публікацій. Відомі нормативні документи [1-3] передбачають проведення лабораторних досліджень визначення теплоти згорання природного газу в хімічних лабораторіях розрахунковим методом [4] на основі хроматографічного аналізу газу або з використанням лабораторних калориметрів [5]. Однак ці методи передбачають вимірювання теплоти згорання в лабораторних умовах тільки сухого газу.

Відоме запатентоване технічне рішення [6] передбачає застосування непрямого методу експрес-визначення теплоти згорання природного газу, який здійснюють шляхом вимірювання швидкості поширення ультразвукових коливань у ньому. При цьому контролюється вміст в газі азоту і діоксиду вуглецю 3 наступним використанням математичної залежності теплоти згорання природного газу від виміряних його параметрів з використанням алгоритмів штучних 
нейронних мереж. Наведений спосіб також стосується вимірювання калорійності тільки сухого газу, оскільки на даний час відсутні моделі, які би враховували вплив вологості на швидкість поширення ультразвуку в природному газі.

Спосіб визначення теплоти згорання горючих газів [7] полягає у вимірюванні температури полум'я пальника при згоранні суміші сухого досліджуваного газу з постійним об'ємним співвідношенням повітря, яке регулюється в залежності від витрати газу, який спалюється. Даний спосіб вимагає використання спеціального обладнання, яке ускладнює технічну реалізацію процесу вимірювання теплоти згорання, при якому також не передбачено врахування впливу вологи на результати вимірювання. Тут також не конкретизована методика $\mathrm{i}$ засоби вимірювання температури полум'я при згоранні досліджуваного газу.

Відомі дослідження щодо застосування термоанемометричного методу контролю теплоти згорання природного газу $[8,9]$ передбачає опосередковане врахування компонентного складу газу на вимірювання його енергії за результатами математичного моделювання [10]. Однак на даний час в моделі функціонування таких вимірювачів відсутні дослідження фактору впливу вологості природного газу на визначення його теплоти згорання.

У відомих закордонних роботах польських науковців $[11,12]$ здійснено аналіз видів палива, в тому числі, їх поділ з точки зору калорійності у відповідності до міжнародних стандартів ISO. В них проаналізований вплив компонентного складу газу на його теплоту згорання, однак також відсутні дослідження щодо впливу вологості газу на його калорійність.

Додамо також, що вплив наявності вологи при згоранні природного газу враховується у нормативних документах, наприклад [4], при розрахунку фізичних властивостей природного газу як різні значення вищої і нижчої теплоти згорання природного газу. При цьому враховується розрахунковим методом вплив вологи (водяної пари), яка утворюється при згоранні природного газу і не враховується можлива наявність в ньому як окремого компонента водяної пари.

Однак, як відомо, при реальних умовах згорання природного газу можуть виникнути ще додаткові дестабілізуючі фактори, які безпосередньо впливають на теплоту згорання газу. Першим є вологість газу, вміст якої кількісно визначається, наприклад, температурою точки роси [5], бо газ не може бути абсолютно сухим. Другим фактором є волога, яка знаходиться в навколишньому середовищі (повітрі), яке використовується для спалювання газу. Ці два додаткових фактори в кінцевому результаті зменшують енергію газу, яка отримується при його спалюванні.

Таким чином потребують розроблення пристрої, які би могли контролювати теплоту згорання реального природного газу методом експрес-контролю безпосередньо у споживачів.

Метою роботи $є$ дослідження впливу конструктивних факторів на технічну реалізацію методу експрес-контролю теплоти згорання природного газу.

Викладення основного матеріалу. За участю авторів запропонований новий спосіб для експрес-визначення теплоти згорання природного газу [13], який базується на вимірюванні температури спалюваного у пальнику газу. При реалізації способу забезпечується згорання суміші постійного об'ємного співвідношення досліджуваного газу з повітрям із застосуванням у конструкції пальника інжекторного забірного пристрою навколишнього повітря i проградуйованого по витраті торцевого звужувального пристрою, через який здійснюється витік газу в польнику при його спалюванні.

Особливістю застосування вказаного нового способу є можливість визначати теплоту згорання не тільки сухих, але і вологих газів, а також газів, які містять різні неспалювані домішки або домішки, при згоранні яких знижується теплота згорання досліджуваного газу. Запропонований спосіб при реалізації предбачає попереднє калібрування пальника, на якому здійснюють спалювання газу щонайменше на трьох сумішах природного газу відомої теплоти згорання, як функцію від робочих параметрів згорання газу. Такий підхід щодо застосування калібрування забезпечує можливість проведення експрес-визначення теплоти згорання практично за будь-яких умов навколишнього середовища і за виміряних значень параметрів природного газу (тиск, температура, густина, вологість) перед звужувальним пристроєм пальника. При цьому проведення попереднього калібрування пальника щонайменше на трьох сумішах природного газу відомої теплоти згорання дозволяе враховувати особливості функціонування пальника на різних сумішах природного газу, що виключає можливість випадкового впливу конструктивних особливостей пальника і недостовірності вимірювань із забезпеченням необхідної точності вимірювання і допустимої величини похибки. 
Таким чином до числа конструктивних факторів реалізації методу експрес-контролю теплоти згорання природного газу можна віднести вплив вологи навколишнього середовища на вимірюване значення температури спалювання газу, вплив конструктивних особливостей пальника, на якому здійснюється спалювання газу, а також особливості технічного підходу до вимірювання температури полум'я спалюваного газу і тривалості процесу вимірювання цієї температури.

При функціонуванні пристрою визначають теплоту згорання $H c$ природного газу за стандартних умов за формулою [14]:

$$
H_{c}=\frac{\left(A \cdot T-B \cdot K_{i} \cdot \varphi \cdot q_{c} \cdot \tau\right)}{q_{c} \cdot \tau},
$$

де $A$ - коефіцієнт конструктивного виконання пальника; $T$ - температура полум'я пальника; $B$ - коефіцієнт теплоти випаровування вологи повітря; $K_{i}$ - коефіцієнт інжекції інжекторного пристрою пальника; $\varphi$ - відносна вологість повітря навколишнього середовища; $q_{c}$ - об'ємна витрата газу через торцевий звужувальний пристрій за стандартних умов; $\tau-$ тривалість пропуску об'єму газу через пальник.

Значення коефіцієнта конструктивного виконання пальника $A$ визначають під час попереднього калібрування пристрою експрес-визначення теплоти згорання щонайменше на трьох сумішах природного газу відомої теплоти згорання як функцію від робочих параметрів згорання природного газу.

Оскільки при спалюванні газу згідно алгоритму (1) необхідне достатньо точне визначення його витрати, то одним із напрямків практичної реалізації може бути застосування первинних перетворювачів з використанням торцевих звужувальних пристроїв.

При цьому об'єм природного газу, що проходить через торцевий звужувальний пристрій, розраховується за формулою:

$$
q_{C}=5,9736 \cdot 10^{-2} \alpha \varepsilon d^{2} K_{\varphi} \sqrt{\frac{P \Delta p}{\rho_{C} T K}},
$$

де $q_{C}-$ об'ємна витрата газу через звужувальний пристрій, ${ }^{3} / \mathrm{c} ; \alpha$ - коефіцієнт витрати звужувального пристрою; $\varepsilon$ - поправний множник на розширення газу; $d$ - діаметр отвору звужувального пристрою пальника; $\Delta p$ - перепад тиску на звужувальному пристрої; $\rho_{C}-$ густина природного газу за стандартних умов; $K_{\varphi}-$ коефіцієнт, який враховує вологість природного газу; $P, T, K$ - абсолютний тиск, абсолютна температура і коефіцієнт стисливості природного газу за умов звужувального пристрою відповідно.

Коефіцієнт витрати $\alpha$ звужувального пристрою визначається експериментальним шляхом при його індивідуальному градуюванні за допомогою еталонного обладнання, наприклад, дзвонової еталонної установки [5].

3 аналізу формули (1) очевидним є вплив другої частини формули, тобто вологості навколишнього середовища (повітря), на результати визначення теплоти згорання природного газу. Тому проаналізуємо вплив цього фактору на вимірювальний процес.

На згорання природного газу також впливає волога, яка безпосередньо міститься в природному газі і поступає разом 3 ним у пальник, а також волога, яка знаходиться в навколишньому повітрі і також поступає до пальника через інжекційний пристрій забору зовнішнього повітря. Тому в реальних умовах використання природного газу нижчу фактичну теплоту $H_{C F}$ його згорання можна розрахувати за формулою:

$$
H_{C F}=H_{C}-H_{R}-H_{\varphi}
$$

де $H_{C}$ - нижча теплота згорання, яка розраховується при хроматографічному аналізі сухого газу, наприклад, за методикою [4]; $H_{R}$ - енергія, яка витрачається на випаровування вологи, що міститься в природному газі; $H_{\varphi}$ - енергія, яка витрачається на випаровування вологи, що міститься в навколишньому повітрі, яке приймає участь у згоранні газу.

Енергію $H_{R}$ від вологи природного газу при умові його згорання при стандартних умовах (абсолютний тиск $101325 \mathrm{~Pa}$, температура $20^{\circ} \mathrm{C}$ ) можна розрахувати за формулою:

$$
H_{R}=c_{W} \cdot m_{1} \cdot\left(T_{T O}-T_{S}\right)+r \cdot m_{1}+c_{P} \cdot m_{1} \cdot\left(T_{P}-T_{T O}\right),
$$

де $c_{W}, c_{P}$ - питома теплоємність води і водяної пари відповідно; $m_{1}-$ маса води в газі; $T_{T o}$, $T_{P}, T_{S}$ - температура пароутворення води, температура полум'я і нормоване значення температури за стандартних умов $\left(20^{\circ} \mathrm{C}\right)$ відповідно; $r$ - питома теплота пароутворення води. 
Вологість природного газу найчастіше оцінюють за температурою точки роси [5]. Тому для моделювання впливу вологості природного газу на його згорання прийнято межі зміни температури точки роси газу в межах від $-20{ }^{\circ} \mathrm{C}$ до $5^{\circ} \mathrm{C}$. Використовуючи відомі алгоритми i номограми [5] цей діапазон можна виразити в одиницях абсолютної вологості природного газу $\left(8 \cdot 10^{-4} \ldots 65 \cdot 10^{-4}\right)$ кг $/ \mathrm{M}^{3}$.

Як відомо, для повного згорання $1 \mathrm{~m}^{3}$ природного газу необхідно $2 \mathrm{~m}^{3}$ кисню, що витікає із стехіометричного рівняння спалювання газу. Враховуючи, що в навколишньому середовищі об'ємна доля кисню складає $21 \%$, то для спалювання 1 м $^{3}$ природного газу необхідний об'єм повітря буде становити $2 / 0,21=9,52 \mathrm{~m}^{3}$. Тому формулу для визначення $H_{\varphi}$ можна записати у вигляді:

$$
H_{\varphi}=9,52 \cdot c_{W} \cdot m_{2} \cdot\left(T_{T O}-T_{S}\right)+9,52 \cdot r \cdot m_{2}+9,52 \cdot c_{P} \cdot m_{2} \cdot\left(T_{P}-T_{T O}\right),
$$

де $m_{2}-$ маса води в 1 м $^{3}$ повітря.

Відносні похибки $\delta$ від впливу вологи на визначення теплоти згорання природного газу розрахуємо за алгоритмами:

$$
\begin{gathered}
\delta_{R}=\frac{H_{F R}-H_{C}}{H_{N}} \cdot 100 \%, \\
\delta_{\varphi}=\frac{H_{F \varphi}-H_{C}}{H_{N}} \cdot 100 \%,
\end{gathered}
$$

де $\delta_{R}-$ похибка від наявності супутньої вологи у природному газі; $\delta_{\varphi}-$ похибка від наявності вологи у повітрі, яке приймає участь у згоранні газу.

Для реалізації алгоритмів (6) і (7) необхідне використання конкретних даних про компонентний склад або нижчу теплоту згорання реальних природних газів, які отримаються на основі їх хроматографічного аналізу.

Результати математичного моделювання зміни відносної похибки $\delta_{R}$ від температури точки роси природного газу (рис. 1а) та відносної похибки $\delta_{\varphi}$ від відносної вологості повітря (рис. 1б) здійснені для конкретних проб газів 3 нижчою теплотою згорання 7759 ккал/ $\mathrm{m}^{3}$, 8145 ккал/ $\mathrm{m}^{3}$ та 8538 ккал/ $\mathrm{m}^{3}$ за умови температури спалювання $450{ }^{\circ} \mathrm{C}$.

На графіках (рис. 1а,б) спостерігається зростання від'ємної похибки при визначенні теплоти згорання природного газу за умови зростання його вологості та вологості навколишнього повітря. Очевидною $\epsilon$ нелінійна зміна відносної похибки $\delta_{R}$ від температури точки роси газу, яка кількісно характеризується межами зміни відносної похибки від 0,01 \% до $0,08 \%$ при зростанні температури точки роси від $-20^{\circ} \mathrm{C}$ до $5{ }^{\circ} \mathrm{C}$. Однак зміна відносної похибки $\delta_{\varphi}$ від вологості навколишнього повітря практично $\epsilon$ лінійною і свідчить про суттєво більшу кількісну зміну похибки від 0,6 \% до 1,6 \% при зростанні відносної вологості повітря від 30 \% до $80 \%$. При цьому для газів із меншою теплотою згорання вплив зміни вологості є більш вагомим i зростає із збільшенням вологи як природного газу так і повітря. Так при зміні калорійності газу від 7759 ккал/ $\mathrm{m}^{3}$ до 8538 ккал/ $\mathrm{m}^{3}$ для газу із $t_{R}=-20{ }^{\circ} \mathrm{C}$ розходження в похибках становить $0,001 \%$, а при $t_{R}=5{ }^{\circ} \mathrm{C}$ воно збільшується до $0,008 \%$. Кількісне значення діапазону зміни похибки від вологи повітря для вказаного діапазону зміни складу природного газу становить 0,05 \% при відносній вологості 30 \% і 0,16 \% при відносній вологості $80 \%$.

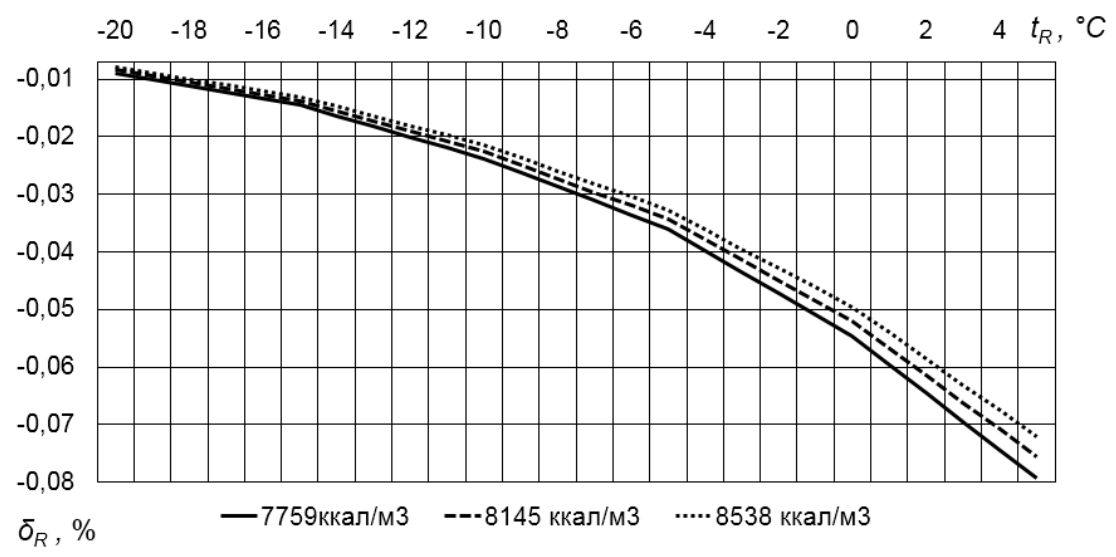

a)

(C) О. Середюк, д.т.н., Н. Малісевич, аспірантка 


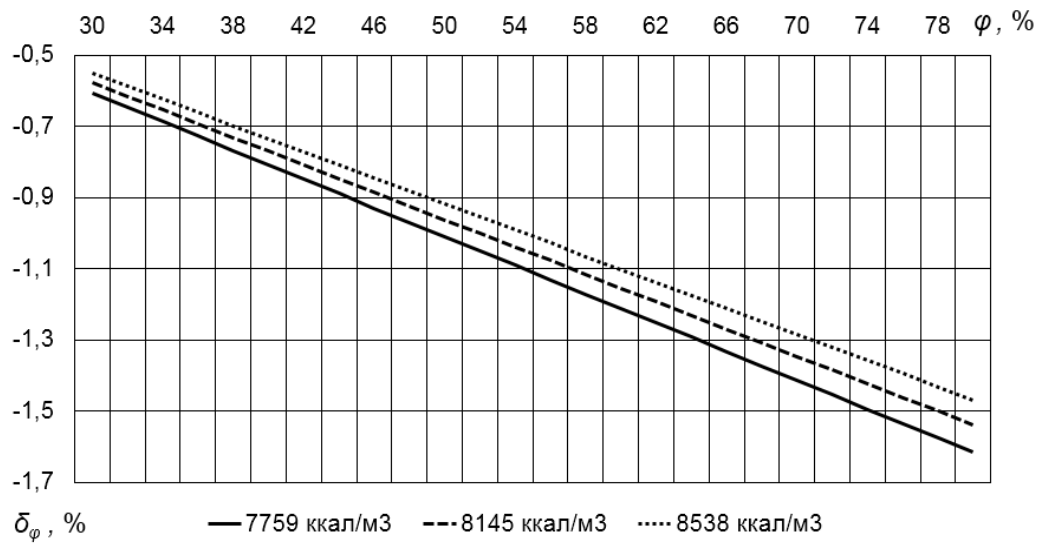

б)

Рис. 1. Графічна ілюстрація зміни відносної похибки при визначенні нижчої теплоти згорання природного газу від температури точки роси (а) та від вологості навколишнього повітря (б)

Для проведення експериментальних досліджень щодо впливу конкретних конструктивних факторів виготовлення пристрою, який реалізує спосіб експрес-визначення теплоти згорання природного газу розроблений лабораторний стенд (рис. 2)

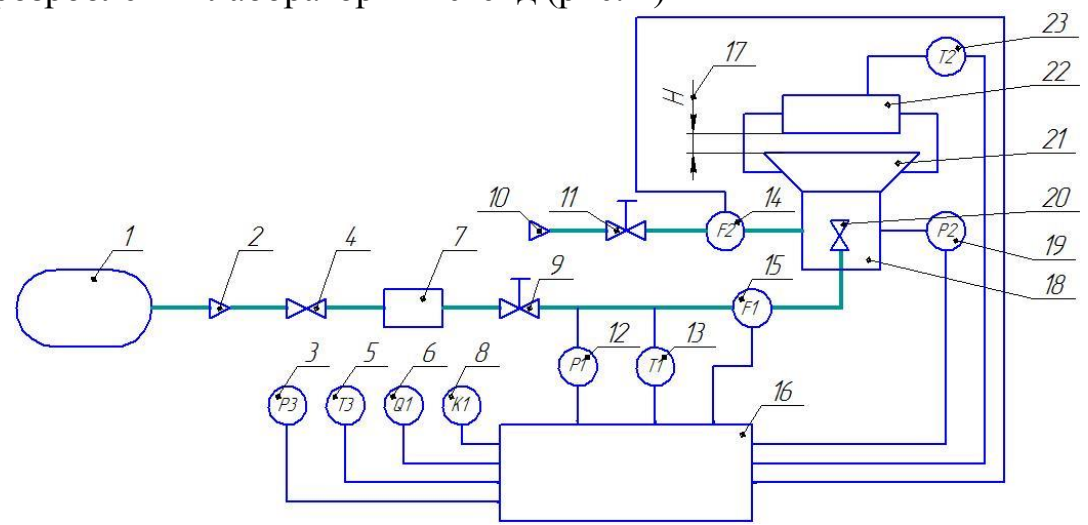

Рис. 2. Схема лабораторного стенду для контролю теплоти згорання природного газу

Лабораторний стенд (рис.2) містить балон 1 зі стиснутим природним газом з відомими його фізико-хімічними показниками, лінію 2 і кран 4 подачі газу, осушувач газу 7, вузол 9 регулювання витрати подачі газу, витратомір 15, , пальник 21 із торцевим звужувальним пристроєм 20. Пальник 21 обладнаний інжектором 18 навколишнього повітря, витрата повітря до якого подається лінією 10, вимірюється витратоміром 14 і задається регулятором 11 . Теплоту згорання вимірюють по температурі пластини 22, яка нагрівається полум'ям пальника 21 , відстань до якої можна регулювати пристроєм 17. Система збору і обробки вимірювальної інформації 16 також містить давачі тиску 12 та температури 13 досліджуваного газу, давач тиску 19 в інжекторі, перетворювач 23 температури пластини, а також давачі тиску 3, температури 5 та вологості 6 навколишнього середовища і цифровий хронометр 8.

Згідно запропонованої методики визначення теплоти згорання природного газу проводиться за його температурою спалювання [13]. Для цього потрібно вимірювати температуру, що може бути полум'я газу.

Як видно з алгоритму (1) для реалізації способу [13] потрібно безпосередньо вимірювати температуру полум'я газу. При цьому алгоритм (1) містить коефіцієнт $A$, який передбачає врахування конструкції пальника та може реалізувати вимірювання температури тіла як функції температури полум'я газу. Тому доцільним $є$ порівняльний аналіз застосування різних технічних підходів до вимірювання температури полум'я для побудови модельного рівняння визначення теплоти згорання природного газу.

Одним із варіантів практичної реалізації вимірювання температури згорання газу може бути визначення температури за ступінню нагрівання пластини. Такий підхід за фіксованих значень витрати газу і витрати повітря буде опосередковано характеризувати теплоту згорання 
природного газу. Однак необхідним при цьому є дослідження місця вимірювання температури пластини, під якою здійснюється згорання газу.

Розроблена схема досліджень (рис. 3) містить пірометр 1, пластину 2, розсікач полум'я 5 із кришкою розсікача 4, витратомір газу 6 та витратомір повітря 7. Полум'я при згоранні газу вказано позицією 3.

Для досліджень вибрано пальник 3 діаметром розсікача полум'я d=80 мм, дві металеві пластини діаметром $\mathrm{D}=140$ мм та товщинами $\delta_{1}=0,8$ мм та $\delta_{2}=2$ мм. Пластини розміщуються над пальником на висоті $\mathrm{h}=10$ мм. При цьому витрата повітря становила $1,47 \cdot 10-4 \mathrm{~m}^{3} / \mathrm{c}$, a витрата природного газу $-1,5 \cdot 10-5 \mathrm{~m}^{3} / \mathrm{c}$.

При дослідженнях суміш природного газу і повітря потрапляе до камери розсікача полум'я 5, звідки виходить назовні через отвори, утворені кришкою розсікача полум'я 4 i згорає. Полум'я 3 нагріває пластину 2, температуру поверхні якої вимірювали пірометром моделі Benetech GM320.

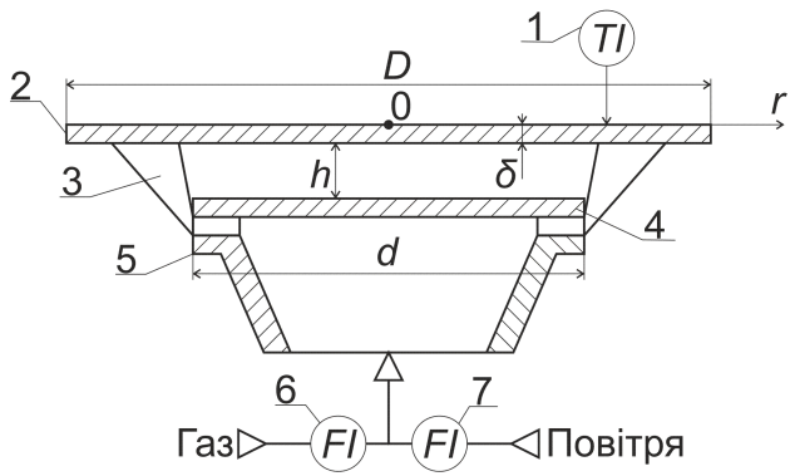

Рис. 3. Схема досліджень температурного поля пластини

Температуру поверхні пластини вимірювали після завершення перехідного процесу, тобто при стабілізації локальної температури на поверхні пластини. Після цього пірометром вимірювали температуру на поверхні пластини вздовж її радіуса з інтервалом 5 мм (рис. 4).

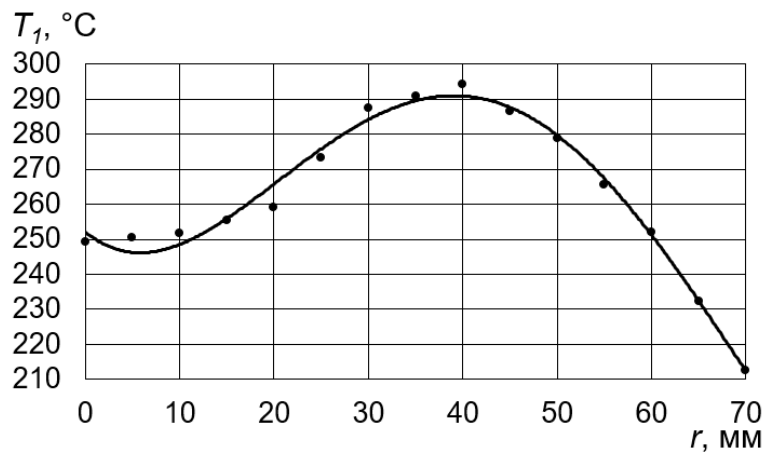

a)

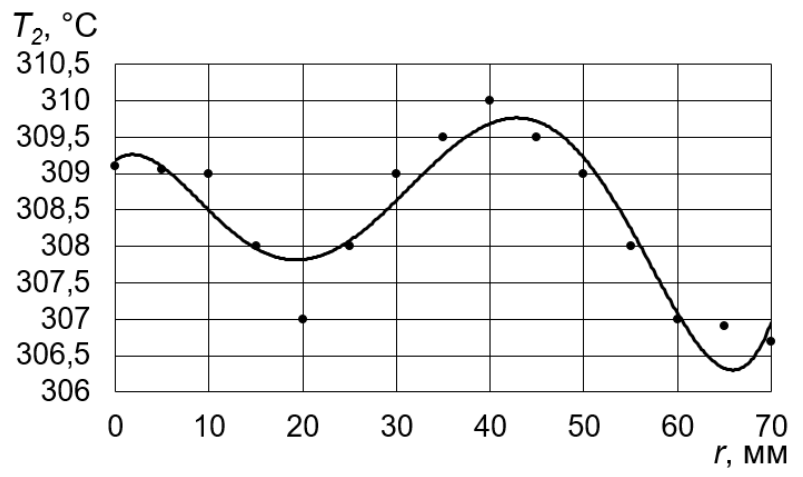

б)

Рис. 4. Графічне зображення залежності температури Т від координати r поверхні пластини товщиною 0,8 мм (а) та 2,0 мм (б)

Отримані експериментальні точки можна апроксимувати такими виразами:

$$
\begin{gathered}
T_{1}=3 \cdot 10^{-5} \cdot r^{4}-4,9 \cdot 10^{-3} \cdot r^{3}+0,2321 \cdot r^{2}-2,2108 \cdot r+252,1 ; \\
T_{2}=2 \cdot 10^{-7} \cdot r^{5}-3 \cdot 10^{-5} \cdot r^{4}+1,6 \cdot 10^{-3} \cdot r^{3}-0,0286 \cdot r^{2}+0,0889 \cdot r+309,19,
\end{gathered}
$$

де $T_{1}, T_{2}$ - температура першої і другої пластини відповідно.

На тоншій пластині є суттєвий градієнт температури вздовж поверхні пластини (зміна температури стосовно розмірів розсікача полум'я становить $40^{\circ} \mathrm{C}$, причому максимальне значення $290^{\circ} \mathrm{C}$ близьке до радіуса розсікача полум'я). Товстіша пластина хоча $\mathrm{i}$ характеризується більш складною формою розподілу температури, однак також іiі максимальне значення близьке до радіуса розсікача полум'я, а градієнт температури є суттєво меншим (близько $4{ }^{\circ} \mathrm{C}$ ). В обох випадках очевидним $€$ зменшення температури внаслідок теплообміну країв пластини $з$ навколишнім середовищем. 
Отримані результати вказують на необхідність врахування конструктивних параметрів пальника, а також товщини пластини.

Для вимірювання безпосередньо температури полум'я $T_{T П}$ досліджено можливість застосування термопари типу К (градуювальна характеристика ТХА) [14]. Для цього проведені додаткові дослідження їх функціонування за умов визначення теплоти згорання природного газу, які характеризуються перебуванням термопари безпосередньо в полум'ї спалюваного газу.

Зони нагрівання термопари умовно були поділені на три частини, як зображено на рис.5. Експериментально встановлено оптимальність нагрівання в зоні 2, як найбільш чутливій до місця її нагріву полум'ям (кожна зона становить третю частину від загальної довжини $l=70$ мм чохла термопари).

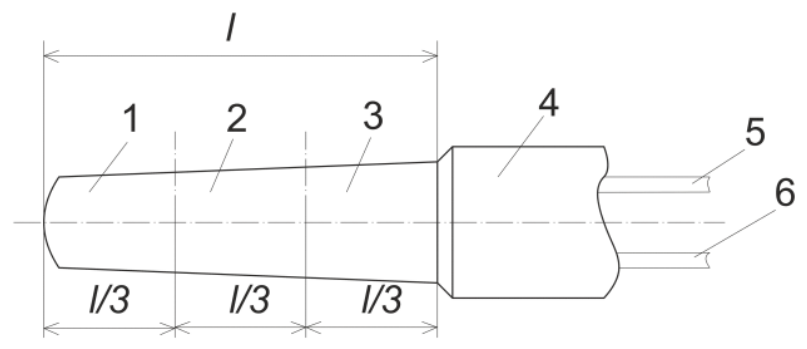

1, 2, 3 - зони нагрівання термопари; 4 - під’єднувальний кабель;

5, 6 - під'єднувальні провідники

Рис. 5. Схема термопари при вимірюваннях температури полум’я природного газу

Також проводилися експериментальні дослідження динамічних характеристик термопари і процесу нагрівання пластин (рис. 6). Результати досліджень свідчать про експоненційний вид залежності вихідного сигналу перетворювача і зміни температури пластин при їх нагріванні полум'ям спалюваного газу. Отримані закономірності відповідають відомим видам динамічних характеристик перетворювачів, як аперіодичної ланки першого порядку. Експериментально встановлено, що постійна часу для термопари К (ТХА) є близькою до 150 с (рис. 6а). При використанні пластини постійні часу суттєво відрізняються і становлять близько 35 с для тонкої пластини і 120 с - для товстої пластини (рис. 6б). За останньої умови постійною часу пірометра, який вимірює температуру пластини, можна нехтувати.

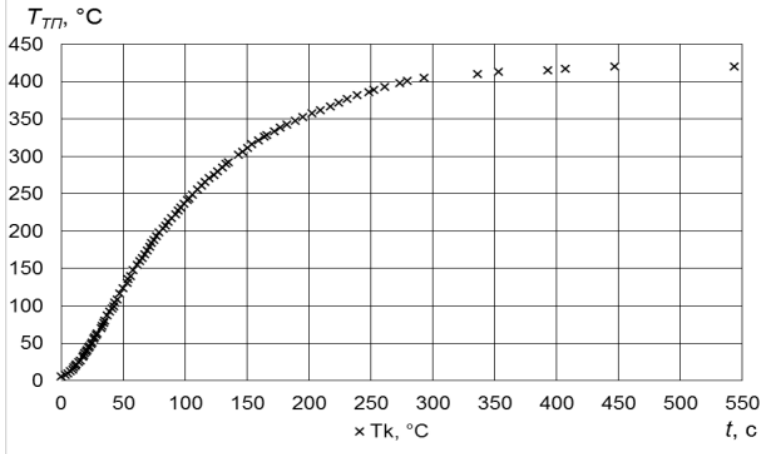

a)

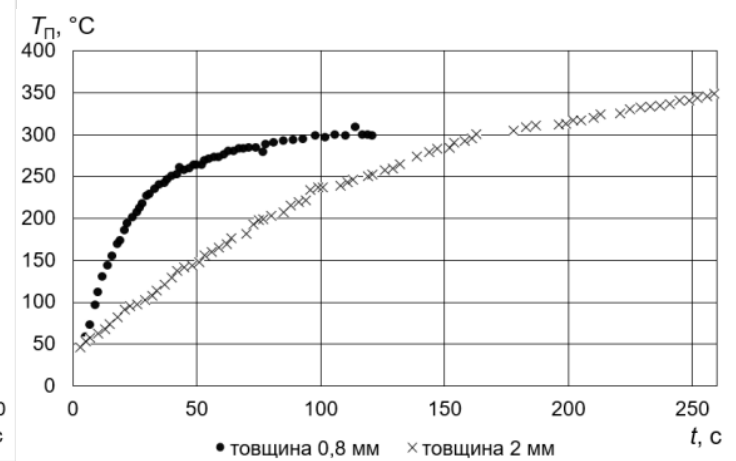

б)

Рис. 6. Графічна ілюстрація динамічних характеристик термопари типу К (ТХА) (а) та зміни температури металевих пластин різної товщини (б)

Отримані результати вказують на необхідність вибору тривалості спалювання газу 3 врахуванням конструктивних особливостей застосовуваних термоперетворювачів i опосередкованого методу вимірювання температури полум'я газу при визначенні теплоти згорання природного газу за його температурою спалювання.

Висновки. Проведено аналіз відомих нормативних методів і технічних рішень для розрахункового і експериментального методу визначення теплоти згорання природного газу. Показано, що практично всі методи передбачають визначення калорійності сухого газу, що досягається його попереднім осушуванням. Розглянуто необхідність визначення теплоти згорання природного газу у споживачів за місцем роботи газоспоживного обладнання. 
Викладено технічне рішення для дослідження запатентованого авторами способу визначення теплоти згорання природного газу прямим методом за температурою згорання газу.

Кількісно оцінена зміна відносної похибки визначення теплоти згорання природного газу від вологи газу і вологи повітря для умов реалізації запропонованого способу визначення теплоти згорання для конкретних трьох проб газу з теплотою згорання 7759 ккал/ $\mathrm{M}^{3}, 8145$ ккал $/ \mathrm{m}^{3}$ та 8538 ккал/м ${ }^{3}$. Встановлено, що із збільшенням вологи газу зростає від'ємна відносна похибка, яка оцінюється 0,08 \% при температурі роси газу плюс $5{ }^{\circ} \mathrm{C}$. Поряд 3 цим збільшення вологості навколишнього повітря може викликати збільшення відносної похибки до мінус 1,6 \% при відносній вологості повітря $80 \%$.

Досліджено вплив конструктивних факторів, які впливають на технічну реалізацію методу експрес-контролю теплоти згорання природного газу. Це стосується моделювання температурного поля поверхні пластини при опосередкованому вимірюванні за допомогою них температури полум'я газу, який спалюється. Встановлено наявність суттєвого градієнта температури вздовж поверхні тонкої пластини та набагато менше її значення для грубшої пластини.

Досліджені динамічні характеристики нагрівання пластини і термопари при вимірюванні температури полум'я, які змінюються в межах від 35 с до 150 с в залежності від конструктивного виконання. Це дозволяє вибирати тривалість вимірювального процесу від впливу конструктивних факторів пальників при спалюванні газу.

Подальші дослідження будуть спрямовані на дослідження впливу співвідношення газповітря на температуру спалювання газу 3 метою визначення підняття чутливості методу експрес-контролю теплоти згорання природного газу. Також буть проведені дослідження по впливу якісних характеристик газу на його температуру спалювання.

\section{Інформаційні джерела}

1. ISO 15112:2007. Natural Gas - Energy determination

2. EN 1776:2015. Gas infrastructure. Gas measuring systems. Functional requirements

3. ДСТУ ISO 15112:2009. Природний газ. Визначення енергії:[Чинний від 2011-01-01]. Вид. офіц. Київ: держспоживстандарт України, 2011. 53 с. (Національний стандарт України)

4. ГОСТ 30319.1-96. Газ природный. Методы расчета физических свойств. Определение физических свойств природного газа, его компонентов и продуктов его переработки: [Чинний від 12.04.1996]. Изд. офиц. Минск, 1996. 21 с. (Межгосударственный стандарт)

5. Облік природного газу: довідник / [М.П.Андріїшин, О.М.Карпаш, Я.С.Марчук, I.С.Петришин, О.С.Середюк, С.А.Чеховський]; за ред. С.А.Чеховського. - Івано-Франківськ: ПП «Сімик», 2008. - $180 \mathrm{c}$.

6. Спосіб експрес-визначення теплоти згоряння природного газу / Карпаш О.М., Дарвай I.Я., Карпаш М.О. [та ін.]: пат. 92846 С2 Україна, МПК (2009) G01N25/20. № a200905201: заявл. 25.05.09; опубл. 10.12.10; Бюл. № 23.

7. Method of and means for accurately measuring the calorific value of combustible gases / William H., Clingman, Jr.: pat. 4062236 United States, IPC G01N 25/30.

8. Serediuk O., Malisevych V., Warsza Z.L., Metoda termoanemometryczna pomiaru wartości energetycznej gazu ziemnego. Przemysł Chemiczny. 2017. T. 96, Nr 11, S. 2243-2246.

9. Малісевич В.В., Середюк О.С. Експериментальні дослідження термоанемометричного витратоміра при обліку природного газу за його енергетичною цінністю. Методи і прилади контролю якості. 2014. №2(33). С.78-85.

10. Serediuk O., Malisevych V., Warsza Z.L., Symulacja związku właściwości cieplnych i energii gazu ziemnego w pomiarach jego przepływu. Przemysł Chemiczny, 2017. T. 96, Nr 10, S. 2065-2069.

11. Roslonek G. Uwarunkowania wdrozenia rozliczen paliw gazowych w jednostkach energii $w$ krajowym systemie gazowniczym / G. Roslonek // Techniki i technologie dla gazownictwa - pomiary, badania, eksploatacja: Konf. Nauk.-Techn. FORGAZ 2014, 15-17 stycznia 2014r., Muszyna: Prace naukowe Instytutu Nafty i Gazu, Nr 194. - Krakow: Instytut Nafty i Gazu, 2014. - S.139-143.

12. Roslonek G. Kierunki rozwoju Standardow Technicznych IGG w obszarze analityki paliw gazowych. Techniki i technologie dla gazownictwa - pomiary, badania, eksploatacja: Konf. Nauk.Techn. FORGAZ 2016, Krakow: Prace naukowe Instytutu Nafty i Gazu. - Krakow: Instytut Nafty i Gazu, 2016. - S.63-70. 
13. Спосіб експрес-визначення теплоти згорання природного газу / Середюк O.С., Лютенко Т.В, Малісевич Н.М.: пат. 112737 C2 Україна, МПК (2006.01) G01N25/20. № а201512215; заявл. 09.12.2015; опубл. 10.10.2016; Бюл. № 19.

14. Середюк О.С., Малісевич Н.М. Аналіз патентозахищених технічних рішень у сфері визначення теплоти згорання природного газу. Методи та прилади контролю якості. 2018. № 1 (40). C. 58-69.

15. https://elcer.com.ua/products/komplektuyushchie/termopary/

\section{О. Середюк, д.т.н., Н. Малисевич, аспирантка}

Ивано-Франковский национальный технический университет нефти и газа

\section{ИССЛЕДОВАНИЕ ВЛИЯНИЯ КОНСТРУКТИВНЫХ ФАКТОРОВ НА ТЕХНИЧЕСКОЕ РЕАЛИЗАЦИИ МЕТОДА ЭКСПРЕСС-КОНТРОЛЯ ТЕПЛОТЫ СГОРАНИЯ ПРИРОДНОГО ГАЗА}

Проведен анализ известных нормативных методов $u$ технических решений для расчетного и экспериментального метода определения теплоты сгорания природного газа. Обоснована необходимость определения теплоты сгорания влажного природного газа у потребителей по месту работы газоспожсивного оборудования. Изложены техническое решение для реализачии запатентованного авторами метода определения теплоты сгорания природного газа прямым методом с температурой сгорания газа. Количественно оиенена изменение относительной погрешности определения теплоты сгорания природного газа от влаги газа и влаги воздуха для условий реализащии предложенного способа определения теплоты сгорания для конкретных трех проб газа с теплотой сгорания $7759 \kappa \kappa a л / \mathrm{M}^{3}$,

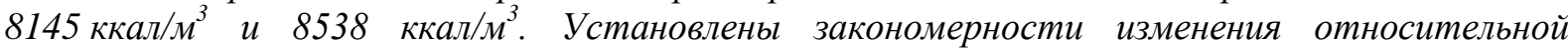
погрешности определения теплоты сгорания от двух составляюших влажности. Осуществлено моделирование относительной погрешности определения теплоты сгорания природного газа одновременно от его влажности и влажности окружающего воздуха. Исследовано влияние конструктивных факторов, влияюших на техническую реализацию метода экспресс-контроля теплоты сгорания природного газа. Установлено наличие существенного градиента температуры вдоль поверхности тонкой пластины и намного меньше ее значение для толще пластины. Исследованы динамические характеристики нагрева пластины и термопары при измерении температуры пламени.

Ключевые слова: природный газ, теплота сгорания, влажность газа, влажность воздуха, термопреобразователи, температура пламени.

\section{O. Serediuk, Doctor of Technical Sciences, N. Malisevich, PhD student}

Ivano-Frankivsk National Technical University of Oil and Gas

\section{RESEARCH OF INFLUENCE OF STRUCTURAL FACTORS ON THE TECHNICAL IMPLEMENTATION OF THE EXPRESS CONTROL METHOD OF NATURAL GAS COMBUSTION}

The analysis of the known regulatory methods and technical solutions for the calculation and experimental method of determining the heat of combustion of natural gas is carried out. The necessity to determine the heat of combustion of wet natural gas by consumers at the place of work of gasconsuming equipment is substantiated. The technical solution for the implementation of the patented method for determining the heat of combustion of natural gas by the direct method of gas combustion temperature. The quantitatively estimated change in the relative error of determination of natural gas combustion heat from gas moisture and air humidity for the conditions of implementation of the proposed method of determining combustion heat for specific three gas samples with combustion heat of $7759 \mathrm{kcal} / \mathrm{m}^{3}, 8145 \mathrm{kcal} / \mathrm{m}^{3}$ and $8538 \mathrm{kcal} / \mathrm{m}^{3}$. The regularities of change of relative error of determination of combustion heat from two components of humidity are established. The relative error of determining the heat of combustion of natural gas simultaneously from its humidity and humidity of the surrounding air is simulated. The influence of design factors that influence the technical implementation of the method of express control of the heat of combustion of natural gas is investigated. The presence of a significant temperature gradient along the surface of the thin plate and much less its value for the coarser plate was established. Dynamic characteristics of plate and thermocouple heating in the measurement of flame temperature are investigated.

Keywords: natural gas, combustion heat, gas humidity, air humidity, thermoconverters, flame temperature. 